\title{
Real-time secondary aerosol formation during a fog event in London
}

\author{
M. Dall'Osto ${ }^{1, *}$, R. M. Harrison ${ }^{1}$, H. Coe ${ }^{2}$, and P. Williams ${ }^{2}$ \\ ${ }^{1}$ National Centre for Atmospheric Science Division of Environmental Health and Risk Management School of Geography, \\ Earth and Environmental Sciences University of Birmingham, Edgbaston, Birmingham B15 2TT, UK \\ ${ }^{2}$ National Centre for Atmospheric Science School of Earth, Atmospheric and Environmental Sciences The University of \\ Manchester, Simon Building Oxford Road, Manchester M13 9PL, UK \\ * now at: Centre for Climate and Air Pollution Studies, Environmental Change Institute, National University of Ireland, \\ Galway, Ireland
}

Received: 7 August 2008 - Published in Atmos. Chem. Phys. Discuss.: 28 November 2008

Revised: 18 February 2009 - Accepted: 19 March 2009 - Published: 3 April 2009

\begin{abstract}
A fog event was monitored with state-of-the art real-time aerosol mass spectrometers in an urban background location in London (England) during the REPARTEE-I experiment. Specific particle types rich in hydroxymethanesulphonate (HMS) were found only during the fog event. Formation of inorganic and organic secondary aerosol was observed as soon as fog was detected and two different mechanisms are suggested to be responsible for the production of two different types of aerosol. Nitrate aerosol is produced in the liquid phase within the droplet. Contrary to previous studies, the formation of HULIS was observed on interstitial particles rather than evaporated fog droplets, suggesting heterogeneous formation mechanisms depending on parameters other than the water content and not fully understood. Not only are secondary aerosol constituents produced during the fog event, but the primary aerosol is observed to be processed by the fog event, dramatically changing its chemical properties.
\end{abstract}

\section{Introduction}

Fogs constitute an aqueous reaction medium in which aerosol mass formation occurs through gas scavenging and chemical reaction in the droplets. Fogs are also involved in aerosol particle scavenging followed by deposition through droplet settling and impaction. The two competing effects depend on several factors: the initial oxidative steps leading to (nonvolatile) particulate organic matter formation are likely to be

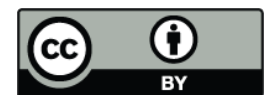

Correspondence to: R. M. Harrison (r.m.harrison@bham.ac.uk) more important at the very beginning of the fog formation when the reactant concentrations are at their maximum whilst deposition rates may increase over time with the growth of fog droplets (Lillis et al., 1999).

Studies of the chemical composition of clouds/fogs have been largely focused on the processing of inorganic compounds. However, recently attention has been given to the organic composition of cloud and droplet fogs (Fuzzi et al., 2002; Herckes et al., 2002; Herckes et al., 2007a, b) and the processing of organic compounds by fogs and clouds (Blando and Turpin, 2000). Reaction pathways for cloud-phase formation of low-molecular weight organic compounds have been studied in detail (Herrmann et al. 2000; Herrmann 2003). However, the reaction pathways to higher molecular weight species are very poorly understood. More generally, the poor understanding of the formation of secondary organic particulate matter represents a major source of uncertainty in predictions of aerosol concentrations and properties affecting health, visibility and climate.

Predictive models and laboratory experiments provide strong support for alkene and aromatic emissions being oxidized in the interstitial air of clouds; the water soluble products partition into cloud droplets, where they oxidize further forming low volatility compounds that remain at least in part in the particle phase after droplet evaporation, forming secondary organic carbon (Blando and Turpin, 2000; Warneck, 2003; Ervens et al., 2004; Gelencser and Varga, 2005; Lim et al., 2005; Altieri et al., 2006; Carlton et al., 2006; Carlton et al., 2007).

Field measurements have provided support to the models and experiments. Several fog episodes were monitored in California's San Joaquin Valley (Herckes et al., 2002; Herckes et al., 2007a, b). The chemical composition of the fogs

Published by Copernicus Publications on behalf of the European Geosciences Union. 
was dominated by nitrogen species (ammonium and nitrate), with important contributions also from organic compounds and sulphate. However, it was concluded that much work still needs to be carried out in order to determine the extent of secondary organic aerosol formation occurring via aqueous phase reaction pathways.

London differs from some of the world's other megacities which have been the subject of air pollution research. Both in Los Angeles (Ning et al., 2007) and Mexico City (Henningan et al., 2008) nitrate formation occurs as a result of oxidation of precursor nitrogen oxides emitted within the city itself. In the case of London, secondary aerosol arises predominantly from advection, having formed outside of the city. Abdalmogith and Harrison (2006) analysed regional sulphate and nitrate data from London and South-East England estimating that $0.46 \mu \mathrm{g} / \mathrm{m}^{3}$ of an annual mean of $3.92 \mu \mathrm{g} / \mathrm{m}^{3}$ for nitrate and $0.22 \mu \mathrm{g} / \mathrm{m}^{3}$ of a annual mean of $2.87 \mu \mathrm{g} / \mathrm{m}^{3}$ for sulphate arises from formation within London. The results reported within this paper were collected during a period when the boundary layer air over London was stagnant, and hence reflect the outcome of local processes, as opposed to longrange transport.

In recent years aerosol mass spectrometry has become available as a powerful tool for the chemical on-line characterization of individual aerosol particles (Murphy, 2007; Noble and Prather, 2000) or small aerosol ensembles (Canagaratna et al., 2007). Here we report the measurement and characterization of aerosol particles detected during a fog event at an urban background location in London by using two types of on-line aerosol mass spectrometers, i.e. ToFAMS and ATOFMS (Time-of-Flight Aerosol Mass Spectrometer and Aerosol Time Of Flight Mass Spectrometer, respectively), as well as a variety of other on-line aerosol instrumentation.

\section{Experimental}

\subsection{Aerosol sampling}

Sampling took place in Regents Park, one of the Royal Parks of London . It is located in the northern part of central London. The park has an outer ring road called the Outer Circle $(4.3 \mathrm{~km})$ and an inner ring road called the Inner Circle. Apart from two link roads between these two, the park is reserved for pedestrians. The park is of about $2 \mathrm{~km}^{2}$ of mainly open parkland. The sampling site chosen was inside the inner circle, in an open area usually reserved for parking and gardening purposes. All the instruments were housed in a mobile laboratory. The site was part of a UK research project called REPARTEE-I (Regent's Park and Tower Environmental Experiment) aiming to study atmospheric chemical processes, and particularly those affecting atmospheric aerosol, in London.
During this campaign, sampling of gases and aerosol was conducted from the top of a $10 \mathrm{~m}$ tall tower constructed at the site. To minimize sampling losses, air was drawn down a vertical sample pipe approximately $150 \mathrm{~mm}$ in diameter, which allowed air to be drawn from above the surrounding tree line. Air was sub-sampled from the main sample flow under superisokinetic conditions, which causes negligible losses below $5 \mu \mathrm{m}$ through a $40 \mathrm{~mm}$ diameter stainless steel pipe with a knife edge forward facing tip, and was taken via a gentle $90^{\circ}$ bend into the air conditioned mobile laboratory.

\subsection{Instrumentation}

At the measurement site two on-line aerosol mass spectrometers were operated, an ATOFMS (Model 3800-100, TSI, Inc.) and a C-ToF-AMS (Compact ToF-AMS, Aerodyne Research, Inc.). The ATOFMS collects bipolar mass spectra of individual aerosol particles. Ambient aerosol is focused through an aerodynamic lens into a narrow particle beam for sizes between $100 \mathrm{~nm}$ and $3 \mu \mathrm{m}$. Using a 2-laser velocimeter particle sizes are determined from particle velocity after acceleration into the vacuum. In addition the light scattered by the particles is used to trigger a pulsed high power desorption and ionization laser $(\lambda=266 \mathrm{~nm}, 1 \mathrm{~mJ} /$ pulse $)$ which evaporates and ionizes the particle in the centre of the ion source of a bipolar reflectron ToF-MS. Thus from an individual particle that is detected in the velocimeter a positive and negative ion spectrum is obtained, reflecting qualitatively the chemical composition of the particle (Gard et al., 1997). The ATOFMS provides information about the abundance of different types of aerosol particles as a function of particle size with high time resolution.

The Aerodyne Compact Time-of-Flight Aerosol Mass Spectrometer (C-ToF-AMS) focuses aerosol particles in the size range $50-600 \mathrm{~nm}$ quantitatively onto a heated surface $\left(\sim 550^{\circ} \mathrm{C}\right)$ using an aerodynamic lens assembly (Zhang et al., 2002; Zhang et al., 2004). Smaller and larger particles are also collected, but with lower efficiency. Non-refractory particle components flash-evaporate on the heated surface; the evolving kinetic gas is electron impact $(70 \mathrm{eV})$ ionized and the ions are extracted orthogonally and sampled by the ToFMS for mass analysis. Particle size information is obtained by chopping the particle beam and collecting mass spectra as a function of particle flight time. The instrument provides 5 minute averaged quantitative mass loading information on non refractory components using a well characterised series of calibrations and error estimations (Jimenez et al., 2003; Allan et al., 2003; Allan et al., 2004), as well as speciesresolved size distributions. A detailed description of the instrument and its operation is given in Drewnick et al. (2005).

In addition to the aerosol mass spectrometers a variety of on-line aerosol instruments were deployed to measure different physical characteristics of the ambient aerosol. A Multi-Angle Absorption Photometer (MAAP, Thermo Electron) was used to measure 1-min averages of the aerosol 
Table 1. Summary of the ATOFMS classes discussed during the fog event (13 October 2006).

\begin{tabular}{llcc}
\hline ATOFMS class & N Particles & \% of the total & \% during the event \\
\hline Nitrate & 43516 & 34 & 52 \\
HMOC-1 & 4865 & 4 & 13 \\
HMOC-2 & About 50 & $<0.1$ & $<1$ \\
Ca-EC & 5496 & 4 & 10 \\
Ca-SUL & About 50 & $<0.1$ & $<1$ \\
HMS & 245 & 0.2 & 4 \\
others & 75443 & 58 & 21 \\
\hline
\end{tabular}

absorption coefficient, from which the ambient black carbon concentrations were calculated. Additionally, an APS (TSI 3321,5 min resolution) DMPS ( $5 \mathrm{~nm}-800 \mathrm{~nm}$, two "Vienna" design DMAs (medium length and short length), 10 min resolution as described by Williams et al., 2007) and CPC (TSI $3776,>2.5 \mathrm{~nm}$ ) were used.

Local meteorological parameters were determined by a Weather Transmitter WXT510 (Vaisala Ltd, Birmingham) probe. Gas measurements were obtained by Thermo Environment 42CTL chemiluminescence gas analyser with thermal converter and by Thermo Environment 49C photometric UV analyzer for $\mathrm{NO}_{\mathrm{x}}$ and ozone, respectively.

\subsection{Data analysis}

The ATOFMS was deployed at Regents Park for 19 days, between 4 October 2006 and 22 October 2006, and detected in total 153595 particles. The TSI ATOFMS dataset was imported into YAADA (Yet Another ATOFMS Data Analyzer) and single particle mass spectra were grouped with Adaptive Resonance Theory neural network, ART-2a (Song et al., 1999). The parameters used for ART-2a in this experiment were: learning rate 0.05 , vigilance factor 0.85 , and iterations 20. Further details of the parameters can be found elsewhere (Dall'Osto and Harrison 2006; Rebotier and Prather 2007). An ART-2a area matrix (AM) of a particle cluster represents the average intensity for each $\mathrm{m} / \mathrm{z}$ for all particles within a group. An ART-2a AM therefore reflects the typical mass spectra of the particles within a group. The ART-2a algorithm generated 306 clusters used to describe the dataset. By manually merging similar clusters (Dall'Osto and Harrison, 2006), the total number of clusters describing the whole database was reduced to about 20. Common particle types including sea salt, soil dust, biomass burning, lubricating oil were attributed to other sources. However, the objective of this study is not to present an overview of all the ATOFMS classes, but to focus on the morning of 13 October 2006. About 7000 single particle mass spectra were acquired by the ATOFMS during the time period discussed in this paper (06:00-14:00). However, ART-2a was run on all datasets and not only on the specific morning of interest, in order to have a broad picture of the field campaign. Specific particle types occurred which were found only during the fog event. Table 1 shows the summary of the 6 ATOFMS particle types herein discussed. The clusters Nitrate and Ca-EC were found also during other periods besides the fog event. However, the clusters, HMOC2, Ca-SUL and HMS (described below) were unique to this event. The six ATOFMS particle types accounted for about $80 \%$ of the particles sampled by the ATOFMS during the morning under consideration.

The C-ToF-AMS was housed next to the ATOFMS and sub-sampled the same aerosol line in the mobile laboratory. The combination of the two instruments provides a comprehensive dataset of the aerosol chemical composition and mixing state of the chemical compounds. The C-ToF-AMS ran from the 4 October 2006 to the 23 October 2006 and generated an almost continuous data set. The data analysis yielded time trends of the major inorganic species (nitrate, sulphate, ammonium and chloride) and total organics as well as the ensemble mass spectrum, particle mass-size distributions as a function of species or mass-to-charge $(\mathrm{m} / \mathrm{z})$ ratio and ensemble mass spectra as function of size. Details of the inversions are given by Allan et al. (2003, 2004), Drewnick et al. (2005) and DeCarlo et al. (2006).

The total organic loading is a summation of all the massto-charge ratios $(\mathrm{m} / \mathrm{z})$ that are known to be organic in nature or have a contributing fraction of the mass which is organic. Ambient organic aerosol can be broadly characterised as either primary or secondary in nature, the former representing freshly emitted or formed and the latter processed aerosol, and it is desirable to try and extract this information from the total organic loading to understand the different processes in the atmosphere. Zhang et al. (2005) developed a technique to extract Hydrocarbon-like Organic Aerosol (HOA) and Oxygenated Organic Aerosol (OOA) information from AMS total organic data, which can be used as a proxy for primary and secondary organic aerosol, respectively. This method based upon Principal Component Analysis uses a series of multi-variate linear regressions to extract the HOA and OOA factors, with the assumption that the total organic loading is the summation of HOA and OOA. The initial guess, or components, are the time trends of $\mathrm{m} / \mathrm{z} 57$ and $\mathrm{m} / \mathrm{z} 44$. M/z 57 is mainly $\mathrm{C}_{4} \mathrm{H}_{9}^{+}$and is representative of freshly emitted particles (HOA) and $\mathrm{m} / \mathrm{z} 44$ is $\mathrm{CO}_{2}^{+}$which is a quantifiable thermal decomposition product of carboxylic acids found in aged, processed aerosol (OOA), and is formed when particles hit the heated surface.

\section{Results and discussion}

\subsection{Overview}

Radiation fog usually forms near the surface under clear skies in association with an anticyclone. Figure 1a shows the atmospheric pressure for the whole duration of the field 


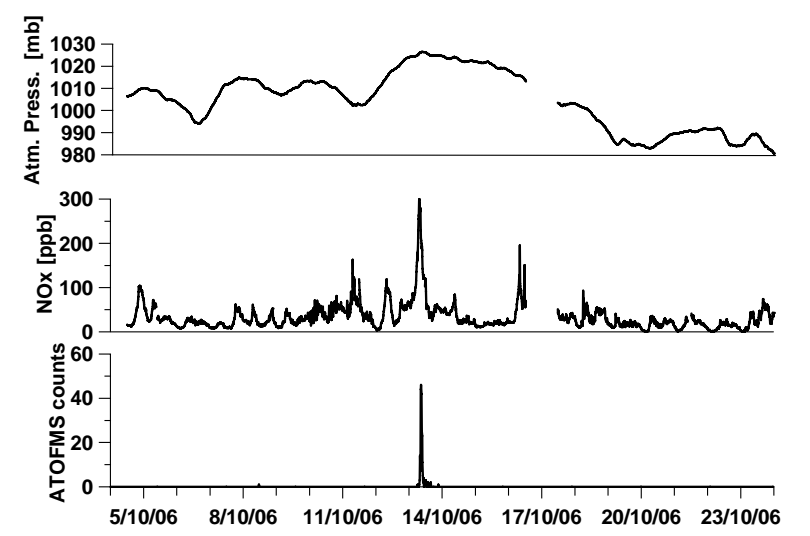

Fig. 1. (a) Atmospheric pressure (mb); (b) $\mathrm{NO}_{\mathrm{x}}(\mathrm{ppb})$ and (c) hourly time series of ATOFMS particle type HMS.

study. The maximum values were detected during the morning of 13 October. Air mass back trajectories showed westerly clean air masses arriving in London on that morning, providing excellent conditions for strong radiative cooling at night, with subsequent dense widespread radiation fogs. Fog was visually seen by the authors on the morning discussed here at about 08:00, lasting for about three hours. Figure 2 shows meteorological parameters for the period considered. The temperature profile at Regents Park (red line, Fig. 2c) starts rising at about 07:00, but it increases very slowly in comparison to other days of the study, due to the presence of the fog. Energy is required to evaporate the fog, delaying the surface heating of the Earth. The lower temperature values detected at the park in comparison to those taken at the BT tower (blue line Fig. 2c; London Telecom Tower - BT tower herein called - is situated about $2 \mathrm{~km}$ away from the sampling site, 150 metres above ground) support the presence of an inversion cap over London. The heavily stagnant conditions are confirmed also by the low wind speed (always below $1 \mathrm{~m} / \mathrm{s}$, Fig. 2b). Furthermore, visibility measurements taken at Heathrow airport by a visiometer (Fig. 2a) confirm the fog event described above, by showing a minimum visibility at about 09:00. The visibility conditions on that morning were the lowest of those detected at Heathrow during the whole month of October. Finally, $\mathrm{NO}_{\mathrm{x}}$ concentrations reached their maximum concentration $(302 \mathrm{ppb}$, reflecting the stagnant conditions) of October 2006 during the morning rush hour period (Fig. 1b) of 13 October, whilst $\mathrm{SO}_{2}$ concentrations did not vary during the day (hourly average $3 \mathrm{ppb})$.

\subsection{Aerosol characterization}

Figure 3 shows temporal trends derived from the real-time particle mass spectrometers (C-ToF-AMS and ATOFMS, Fig. $3 \mathrm{a}$ and $\mathrm{b}$, with 5 and $15 \mathrm{~min}$ time resolution, respectively), along with real-time size-resolved particle number concentrations (APS and DMPS, 10 minutes resolution,

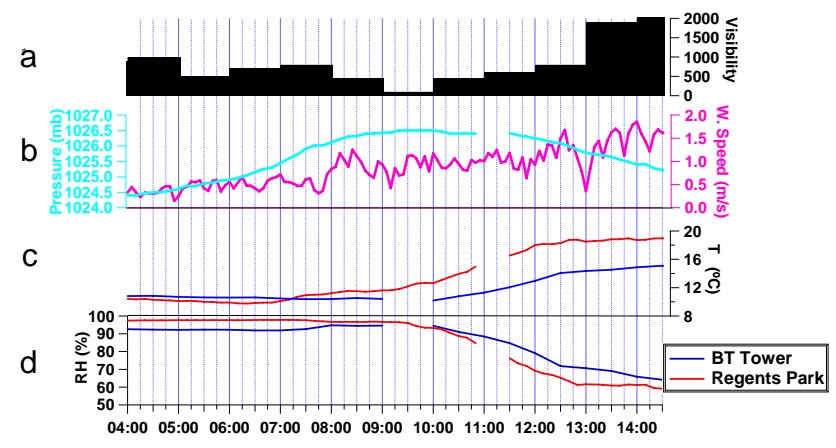

Fig. 2. Summary of meteorological parameters during REPARTEEI (London 2006) during the morning of the 13 of October 2006.

Fig. 3c and d, respectively) and CPC (1 min), along with the total DMPS particle counts in Fig. 3d. Finally, $\mathrm{O}_{3}$ and $\mathrm{NO}_{\mathrm{x}}$ gas measurements (ppb) with Elemental (Black) Carbon (BC, 5 min resolution) appear in Fig. 3e. Unfortunately no data were available from the DMPS until about 10:10 on 13 October 2006 (since 16:00 on 12 October 2006). The morning time series can be split into four different periods: period one (05:00-08:00); period two (08:00-11:00); period three (11:00-12:30) and period four (after 12:30) as shown in Fig. 3.

Period 1 is dominated by the rush hour morning pollutants. AMS hydrocarbon-like organic aerosol (HOA) (Fig. 3a) shows a large increase between 05:30 a.m. and 08:30 a.m., from about 4 to $10 \mu \mathrm{g} / \mathrm{m}^{3}$. Very high correlation $\left(R^{2}>0.75\right)$ can be seen between HOA, BC, and $\mathrm{NO}_{\mathrm{x}}$ (Fig. 3a, e), all good markers for primary vehicular atmospheric pollutants.

AMS HOA mass concentrations decrease continuously after the rush hour peak at about 08:00 a.m. for the whole morning, going to below $0.5 \mu \mathrm{g} / \mathrm{m}^{3}$ in the early afternoon. ATOFMS particle type Ca-EC dominates during this period (Fig. 3b). This particle type was detected during rush hours for the whole duration of the field study and is due to the lubricating oil emitted by traffic. The lubricating oil particle mass spectra (Ca-EC, Fig. 4a) are dominated by calcium $\left(\mathrm{m} / \mathrm{z} 40[\mathrm{Ca}]^{+}\right.$and $\left.\mathrm{m} / \mathrm{z} 57[\mathrm{CaOH}]^{+}\right)$in the positive mass spectra and elemental carbon cluster weak peaks in the negative spectra $\left(\mathrm{m} / \mathrm{z} 36\left[\mathrm{C}_{3}\right]^{-}, 48\left[\mathrm{C}_{4}\right]^{-}\right.$and $\left.60\left[\mathrm{C}_{5}\right]^{-}\right)$(Spencer et al., 2006). The strong peaks at $\mathrm{m} / \mathrm{z}-46$ and $\mathrm{m} / \mathrm{z}-62$ $\left(\left[\mathrm{NO}_{2}\right]^{-}\right.$and $\left[\mathrm{NO}_{3}\right]^{-}$respectively) indicate already some degree of atmospheric aging (Toner et al., 2008).

The beginning of period 2, at about 08:00 is defined by the detection of an ATOFMS particle type named HMS (hydroxymethanesulphonate). This unique particle type was detected only between about 08:00 a.m. and 10:00 a.m. on 13 October and was not observed at any other time during the whole period of the field study (Fig. 1c). The average positive and negative spectra of cluster HMS are shown in Fig. $4 \mathrm{~b}$. The presence of ammonium $\left(\mathrm{m} / \mathrm{z} 18\left[\mathrm{NH}_{4}\right]^{+}\right)$, elemental carbon $\left(\mathrm{m} / \mathrm{z} 36\left[\mathrm{C}_{3}\right]^{+}, 48\left[\mathrm{C}_{4}\right]^{+}\right.$and $\left.60\left[\mathrm{C}_{5}\right]^{+}\right)$, oxidised carbon 


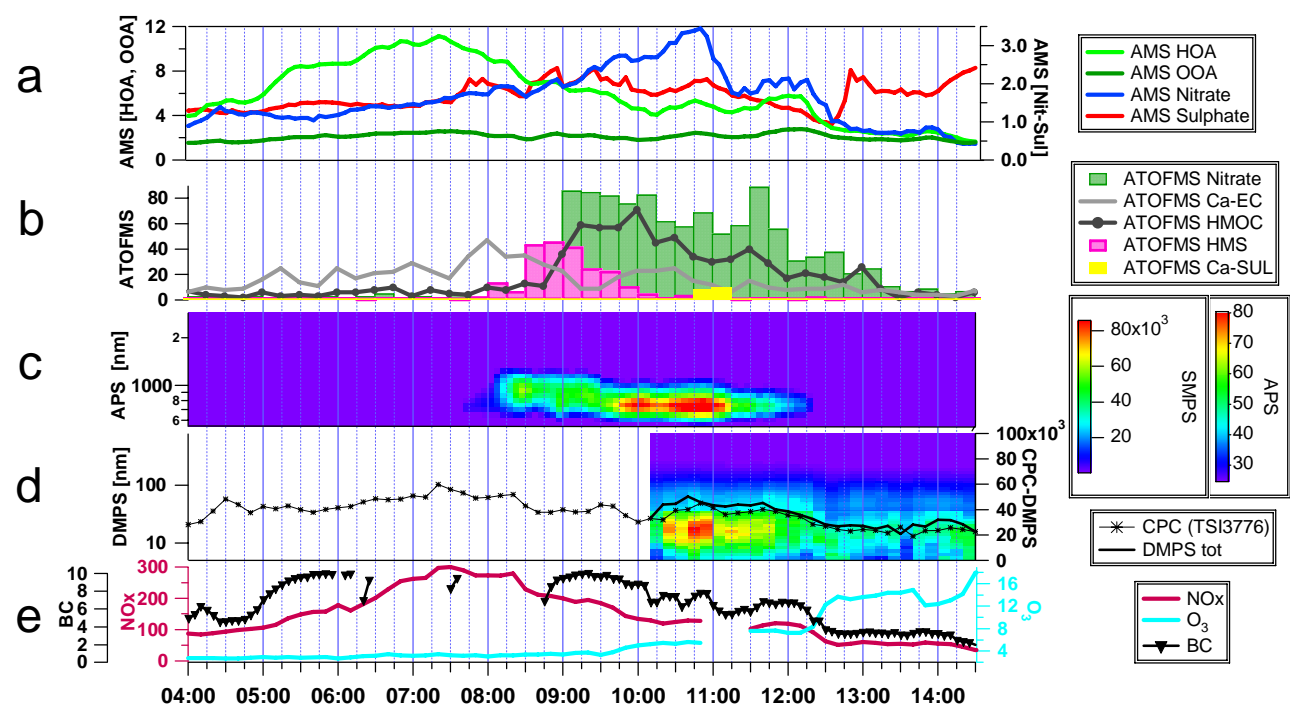

Fig. 3. (a) AMS mass loading $\left(\mu \mathrm{g} / \mathrm{m}^{3}\right)$ for hydrocarbon-like organic aerosol (HOA), oxygenated organic aerosol (OOA), nitrate and sulphate (b) ATOFMS high resolution temporal trends for nitrate, Ca-EC, Hydroxymethanesulphonate (HMS), high mass organic carbon (HMOC) and Calcium/Sulphate-rich (Ca SUL) particle types; (c) APS and (d) DMPS size distributions ( $d$ N/dlog Dp) with CPC particle number concentrations $\left(\mathrm{p} / \mathrm{cm}^{3}\right)$ and (e) $\mathrm{BC}\left(\mathrm{MAAP}, \mu \mathrm{g} / \mathrm{m}^{3}\right), \mathrm{NO}_{\mathrm{x}}$ and $\mathrm{O}_{3}$ gas concentrations (ppb).

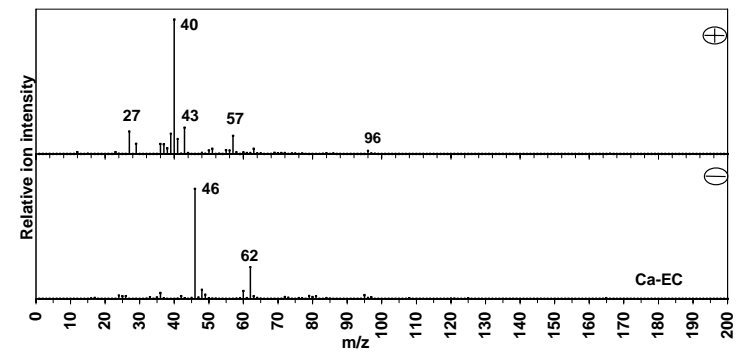

$\mathrm{a}$

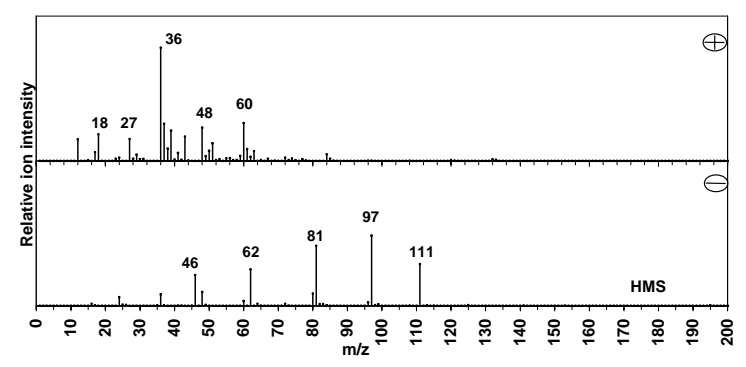

b

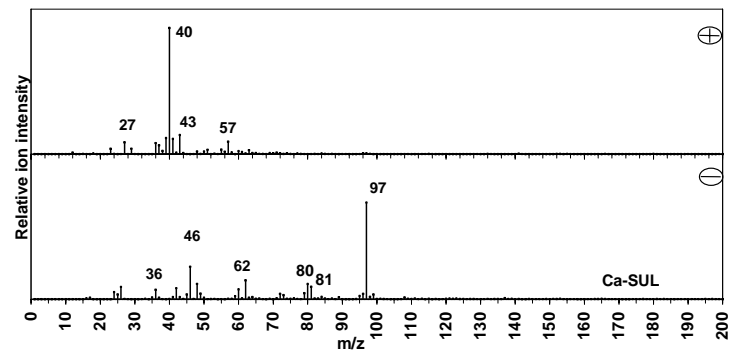

C

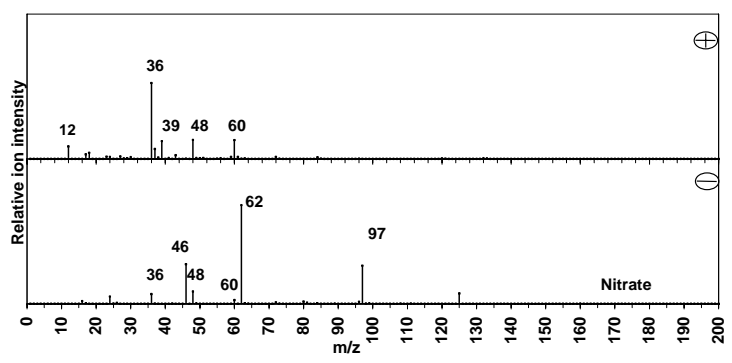

d

Fig. 4. Positive (+) and negative (-) ART-2a area vectors attributed to the ATOFMS particle type (a) Ca-EC; (b) HMS, (c) Ca-SUL and (d) Nitrate.

$\left(\mathrm{m} / \mathrm{z} 27\left[\mathrm{C}_{2} \mathrm{H}_{3}\right]^{+}\right.$and $\left.43\left[\left(\mathrm{CH}_{3}\right) \mathrm{CO}\right]^{+}\right)$can be seen in the positive mass spectra, whilst the negative mass spectra show the presence of nitrate $(\mathrm{m} / \mathrm{z}-46$ and $\mathrm{m} / \mathrm{z}-62)$. The unique mass series of $\mathrm{m} / \mathrm{z}-81,-97$ and $\mathrm{m} / \mathrm{z}-111$ is due to species
$\left[\mathrm{HSO}_{3}\right]^{-},\left[\mathrm{HSO}_{4}\right]^{-}$and $\left[\mathrm{HOCH}_{2} \mathrm{SO}_{3}\right]^{-}$. ATOFMS particle spectra of this type have previously been shown to arise from hydroxymethanesulphonate in both laboratory studies and field experiments (Whiteaker and Prather, 2003). The 
scaled ATOFMS size distribution of this particle type shows a sharp unimodal peak at about $0.85 \mu \mathrm{m}$ (Fig. 7). ATOFMS size distributions were obtained by scaling the ATOFMS particle number counts with DMPS and APS particle number size distributions. It should be stressed that the size distributions presented in this work have only qualitative meaning, as the ATOFMS efficiency is different for different particles and each broad type of particles exhibits a different hit rate (Reinard et al., 2007).

The APS size distributions (Fig. 3c) confirm this finding, showing an increase of particles at about $0.8-1.0 \mu \mathrm{m}$ in association with the detection of the ATOFMS HMS particle type. The formation and stability of HMS has been shown to be highly dependent on the $\mathrm{pH}$ of the particle or droplet, as well as the concentrations of other chemical species (Kok et al., 1986; Lagrange et al., 1999). HMS is exclusively formed in the aqueous phase, so its presence in particles is a valuable tracer for processing by aqueous phase chemistry.

$$
\begin{aligned}
& \mathrm{SO}_{2}(\mathrm{~g})+\mathrm{H}_{2} \mathrm{O} \Longleftrightarrow \mathrm{SO}_{2} \cdot \mathrm{H}_{2} \mathrm{O} \\
& \mathrm{SO}_{2} \cdot \mathrm{H}_{2} \mathrm{O} \Longleftrightarrow \mathrm{H}^{+}+\mathrm{HSO}_{3}^{-} \\
& \mathrm{HSO}_{3}^{-} \Longleftrightarrow \mathrm{H}^{+}+\mathrm{SO}_{3}^{-} \\
& \mathrm{HCHO}(\mathrm{aq})+\mathrm{H}_{2} \mathrm{O} \Longleftrightarrow \mathrm{CH}_{2}(\mathrm{OH})_{2}
\end{aligned}
$$

$\mathrm{HCHO}(\mathrm{aq})+\mathrm{HSO}_{3}^{-} \Longleftrightarrow \mathrm{HOCH}_{2} \mathrm{SO}_{3}^{-}$(unique $\mathrm{m} / \mathrm{z}$ -111 seen in Fig. 3b)

$$
\mathrm{HCHO}(\mathrm{aq})+\mathrm{SO}_{3}^{2-} \Longleftrightarrow-\mathrm{OCH}_{2} \mathrm{SO}_{3}^{-}
$$

Several studies have reported sulphate production by fog/clouds (Laj et al., 1997). However, recent measurements of fog sample composition (Herckes et al., 2007a) show domination by nitrogen species, with ammonium and nitrate being the most abundant compounds. Fog droplets were found to have a $\mathrm{pH}$ well above 6 , showing a significant decrease in fog concentration of sulphate and increase in fog $\mathrm{pH}$ in comparison to samples taken before the 1980s. The formation rate of HMS increases with $\mathrm{pH}$ and reaches competitive levels with sulphur oxidation rates at $\mathrm{pH}$ levels higher than 5 (Whiteaker and Prather, 2003). The C-ToF AMS shows a low and weakly varying sulphate aerosol mass loading during this time period (Fig. 3a).

In conjunction with the HMS ATOFMS particle type, three other particle types were detected: high mass organic carbon 1 and 2 ("HMOC 1" and "HMOC 2") as well as "nitrate". The ATOFMS spectra of cluster HMOC1 are shown in Fig. 5. The dominant feature is the presence of secondary organic carbon species $\left(\mathrm{m} / \mathrm{z} 27\left[\mathrm{C}_{2} \mathrm{H}_{3}\right]^{+}\right.$and $\left.43\left[\left(\mathrm{CH}_{3}\right) \mathrm{CO}\right]^{+}\right)$, along with a strong aromatic signature $\left(\mathrm{m} / \mathrm{z} 51\left[\mathrm{C}_{4} \mathrm{H}_{3}\right]^{+}\right.$and 77 $\left.\left[\mathrm{C}_{6} \mathrm{H}_{5}\right]^{+}\right)$. The negative mass spectra show that this particle type is internally mixed with nitrate $(\mathrm{m} / \mathrm{z}-46$ and $\mathrm{m} / \mathrm{z}-62)$ and sulphate $(\mathrm{m} / \mathrm{z}-97)$. Furthermore, very important unique

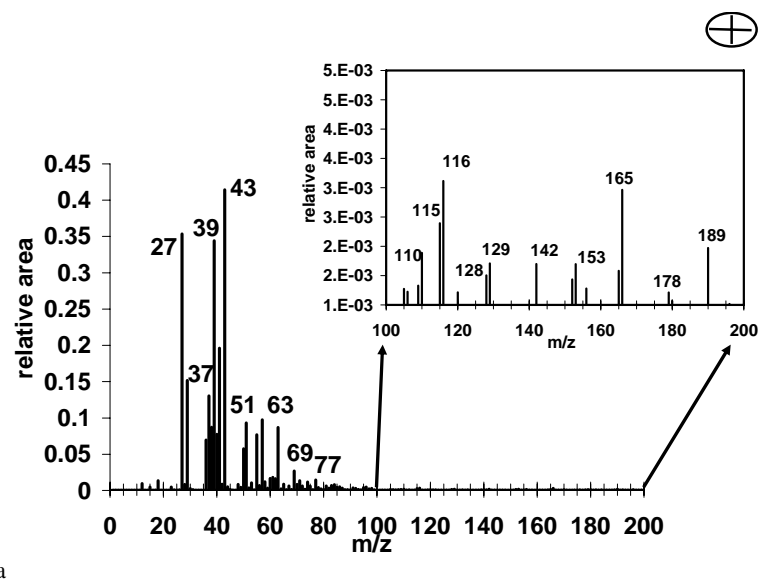

a

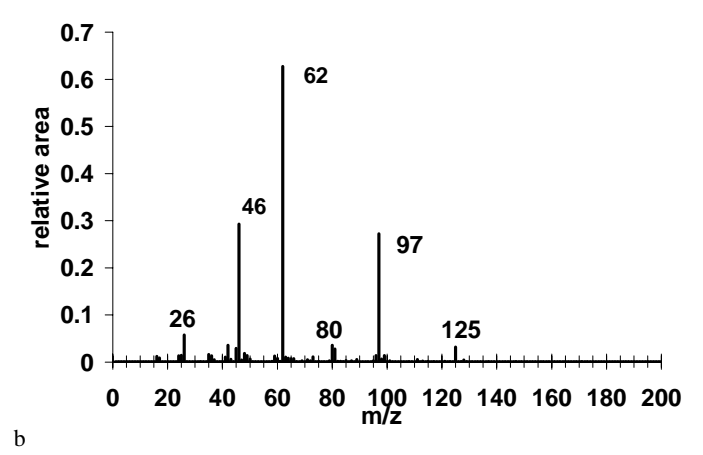

Fig. 5. Positive (a) and negative (b) ART-2a area vectors attributed to HMOC1.

$\mathrm{m} / \mathrm{z}$ peaks can be seen in the high $\mathrm{m} / \mathrm{z}$ region ( $\mathrm{m} / \mathrm{z}$ 100-200). Specific peaks can be seen at $\mathrm{m} / \mathrm{z} 110,115$ 129, 142, 153, 165 and 189. It is important to note that $\mathrm{m} / \mathrm{z} 63\left[\mathrm{C}_{5} \mathrm{H}_{3}\right]^{+}$, $\mathrm{m} / \mathrm{z} 115\left[\mathrm{C}_{9} \mathrm{H}_{7}\right]^{+}, \mathrm{m} / \mathrm{z} 165\left[\mathrm{C}_{13} \mathrm{H}_{9}\right]^{+}$and $\mathrm{m} / \mathrm{z} 189\left[\mathrm{C}_{15} \mathrm{H}_{9}\right]^{+}$ are markers for polyaromatic species. Qin and Prather (2006) have already reported these ATOFMS positive and negative mass spectra, where the presence of similar peaks were associated with HULIS species formed by fog processing. Moreover, similar particles were also seen in another ATOFMS study (Moffet et al., 2008).

Definitive assignments for the high $\mathrm{m} / \mathrm{z}$ peaks $(\mathrm{m} / \mathrm{z}$ above 100) are difficult to make a priori since several possibilities exists for each $\mathrm{m} / \mathrm{z}$ value and speculation will not be attempted. However, some similarities found with the literature can be reported. There have been few attempts to characterise isolated HULIS by molecular weight (Graber and Rudich, 2006) with mass spectrometry.

Kiss et al. (2001; 2003) analysed the organic compounds present in fog water by LC-MS. Major $\mathrm{m} / \mathrm{z}$ peaks likely due to the $\mathrm{M}-\mathrm{H}^{+}$molecular weight at 139,153 , and 165 were obtained. ATOFMS mass spectra show similar major peaks in the range $\mathrm{m} / \mathrm{z} 100-200$ at $\mathrm{m} / \mathrm{z} \mathrm{152,} 153$ and 165. boxMoreover, Krivacsy et al. (2001) reported sizeexclusion chromatography and capillary electrophoresis of 

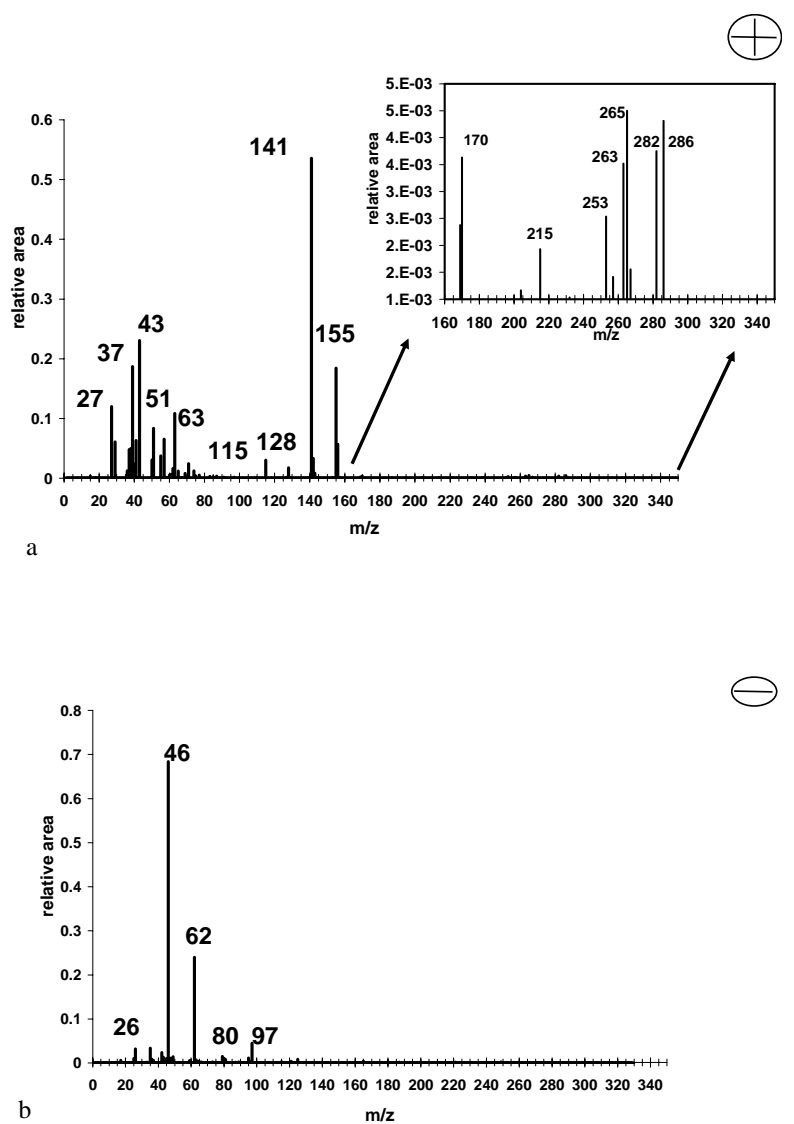

Fig. 6. Positive (a) and negative (b) ART-2a area vectors attributed to HMOC2.

HULIS found in fog water. The two strongest signals detected by negative electrospray ionisation were found to be at $\mathrm{m} / \mathrm{z} 113$ and 187. ATOFMS spectra of cluster HMOC-1 shows the presence of strong signals at m/z 115 and 189 in the $\mathrm{m} / \mathrm{z}$ range $100-200$. We hypothesise that the ATOFMS detects the same parent ion (M) in the positive form $(\mathrm{M}+1)$, whilst the study by Krivacsy et al. (2001) reported the negative form (M-1). Krivacsy et al (2001) concluded that "based on the SEC analyses it can be concluded that the organic components of fog samples were similar to humic reference materials in terms of retention behaviour, UV and fluorescence spectra, complexity and character of the MS spectra and the ability of forming negative ions (i.e. presence of acidic functional groups)."

A second type of ATOFMS cluster called HMOC2 was detected only during this period and its ART-2a positive and negative spectra are shown in Fig. 6a and b. Interestingly, the major signals are found in peaks at $\mathrm{m} / \mathrm{z} 141$ and 155 . To our knowledge, this is the first time this ATOFMS mass spectrum is reported in the literature. Strong signals at high $\mathrm{m} / \mathrm{z}$ in ATOFMS mass spectra have been previously reported, especially due to polycyclic aromatic compounds (Gross et al., 2000; Silva and Prather, 2000), but not with this mass se- ries. These two strong fragments (separated by delta $\mathrm{Z}=14$ ) suggest the detection of a rather stable compound. The strong peak at $\mathrm{m} / \mathrm{z}+37$ suggests a strong organic signature $\left(\left[\mathrm{C}_{3} \mathrm{H}\right]^{+}\right)($Spencer and Prather, 2006) and peaks at $\mathrm{m} / \mathrm{z}+27$ and $\mathrm{m} / \mathrm{z}+43$ confirm the presence of secondary organic carbon. We believe this particle type is a second type of unidentified HULIS. Moreover, minor but important peaks can be seen at $\mathrm{m} / \mathrm{z} 170,215,253,265,282$ and 286 . Peaks at $\mathrm{m} / \mathrm{z}$ at 141, 155, 282 and 286 were also reported by Feng and Moller (2004), in the analysis of $\mathrm{m} / \mathrm{z}$ signals in WSOC from cloud water. One cluster was specifically attributed to polycarboxylic acids formed in an atmospheric polymerization process from low molecular weight organics of different origin in cloud water. Furthermore, the positive spectrum of Cluster HMOC2 shows the strongest signal at $\mathrm{m} / \mathrm{z} 265$ in the $\mathrm{m} / \mathrm{z}$ range $200-350$. It is interesting to note the third most intense peak obtained by a two-stage ion-trap mass spectrometer equipped with electrospray ionisation was at $\mathrm{m} / \mathrm{z} 265$ from a fog sample collected in Italy (Cappiello et al., 2003). Secondary aerosol production though cloud processing was modelled by Lim et al. (2005) and formation of oligomers in clouds from VOC has recently been observed (Altieri et al., 2006; Loeffler et al., 2006). Our study suggests that HULIS appears to be produced on the surfaces of interstitial aerosol forming secondary organic aerosols. Moreover, the real-time single particle information obtained by the ATOFMS indicates that the formation of these high mass organic carbon species occurs during a fog event of only a few hours.

The unique single particle information on the organic matter content obtained by the ATOFMS did not show any obvious correlation with the AMS organic mass loading time series. AMS oxidised organic aerosol (OOA) does not show any increase, with a constant concentration of about $2 \mu \mathrm{g} / \mathrm{m}^{3}$ during the whole day (Fig. 3a). In recent years high molecular weight compounds or oligomers have been detected by several authors who analyzed laboratory-generated secondary organic aerosols (SOA) using particle mass spectrometry. In general, HULIS are considered refractory organic molecules that can only be thermally vaporised from 400 $600^{\circ} \mathrm{C}$ (Andreae and Gelencser, 2006). Recent smog chamber experiments have shown that the ATOFMS can detect oligomeric species (Gross et al., 2006) whilst the AMS provides other very useful information but may not be able to detect oligomeric species well (Alfarra et al., 2006). Additionally, as the AMS is responding to aerosol mass, it will inevitably be of less sensitivity towards minor components of the aerosol.

Along with the ATOFMS organic particle types HMOC1 and HMOC2, a third type of particle was detected soon after the HMS event, mainly composed of nitrate aerosol. The mass spectra of ATOFMS cluster nitrate are shown in Fig. 4d. This particle type was detected also during other events during this field study, mainly associated with nitrate aerosol due to long range transport of pollutants from mainland Europe. This nitrate aerosol was found to be internally mixed with 


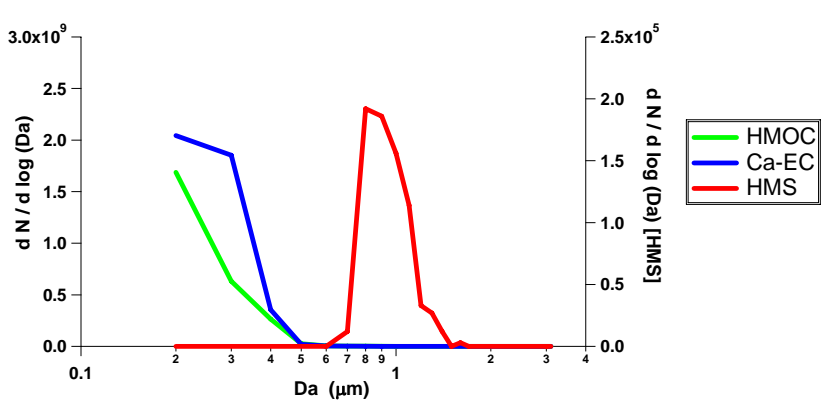

Fig. 7. ATOFMS scaled size distribution for particle types HMOC, Ca-EC and HMS.

elemental carbon and sulphate, and to present a size distribution in the accumulation mode. The ART-2a positive and negative spectra (Fig. 4d) show the presence of nitrate $(\mathrm{m} / \mathrm{z}$ -46 and -62$)$, sulphate $(\mathrm{m} / \mathrm{z}-97)$ and elemental carbon $(\mathrm{m} / \mathrm{z} 36,48$ and 60$)$ in the positive and negative ATOFMS spectra.

Despite the fact that no correlation was found between the ATOFMS and the AMS regarding the organic aerosol fraction, the presence of the nitrate aerosol detected by the ATOFMS during the fog event was also clearly reflected in the AMS data. The AMS nitrate aerosol mass loading, as shown in Fig. 3a, increases by a factor of 3 during the period 2 , reaching its maximum at about 10:30.

The scaled ATOFMS particle size distributions of the three particle types described above and formed during the fog event provide further important information. Whilst the ATOFMS nitrate particle type presented a similar mode to the ATOFMS HMS $(0.8-0.9 \mu \mathrm{m}$, Fig. $7-$ confirmed by the significant increase in the APS particle number concentrations in the same size range and the AMS nitrate aerosol mass loading size distribution), cluster HMOC1 showed a peak in the smallest detectable ATOFMS size at $200 \mathrm{~nm}$ (Fig. 7). The HMOC2 particle type was characterised by particles smaller than $400 \mathrm{~nm}$, but slightly bigger than cluster HMOC1.

Our results suggest that the unique HMOC particle types (HMOC1 and HMOC2) are formed only in the interstitial air, not in evaporated fog droplets, suggesting heterogeneous formation mechanisms depending on parameters other than the water content and not fully understood. The nitrate aerosol is instead formed via aqueous phase processes within the droplets during the fog events, as for HMS.

During a study conducted in the Fresno Valley (California), Qin and Prather (2006) reported biomass particles with distinct diurnal variations, peaking at night and reaching a minimum during the day. In addition to biomass particles, a very similar particle type to our HMOC type was also detected. The temporal variations of HMOC and biomass counts tracked each other very well with a high correlation coefficient of 0.84. Although biomass and HMOC particle types had very similar temporal variations and many common peaks in their mass spectra, the particle size distribu- tions of these two types differed from one another. The majority of the biomass particles were submicron $(\mathrm{Da} \leq 1.0 \mu \mathrm{m})$ with aerodynamic diameters peaking in the lowest detectable sizes $(0.5 \mu \mathrm{m})$. Conversely, the HMOC and fog processed particles (fog processing marker peaks at $\mathrm{m} / \mathrm{z}-81\left[\mathrm{HSO}_{3}^{-}\right]$ and $\mathrm{m} / \mathrm{z}-111\left[\mathrm{HOCH}_{2} \mathrm{SO}_{3}^{-}\right]$; basically the main markers of our HMS particle type, Fig. 4b) were primarily supermicron sized particles $(D \mathrm{a}>1.0 \mu \mathrm{m})$ and had similar size distributions. From all the above evidence, Qin and Prather (2006) suggested that the HMOC particles mainly resulted from a combination of biomass combustion, gas/particle partitioning of semivolatile biomass precursors, followed by aqueous phase processing. However, they could not exclude the possibility that a small fraction of HMOC were HULIS directly emitted from biomass emissions, since HULIS has also been reported to be released from primary biomass emissions. They hypothesised that the observed diurnal variation was due to an increase in direct biomass emissions during night time, followed by gas/particle partitioning of semivolatile species which undergo aqueous phase processing at night. Our results show instead a much finer particle size distribution for the HMOC particle type $(<300 \mathrm{~nm})$ than the droplet mode (1-2 $\mu \mathrm{m}$ in their case). We believe that the peaks associated with HMOC detected by Qin and Prather (2006) are indeed due to fog processing. However, the fact they are found in both the fine biomass particles (freshly emitted) and the coarser HMOC particle type (more fog processed) probably indicates that the meteorological situation was rather stagnant throughout their field study. In other words, they did indeed detect HMOC particles linked with fog processing, but the mechanism of formation remains unclear. Our study suggest for the first time in real time that the formation of HULIS was observed on interstitial particles and not in evaporated fog droplets, suggesting heterogeneous formation mechanisms.

These different ATOFMS size distributions for HMOC and nitrate particle types are important, showing different pathways of secondary aerosol production. Yao et al. (2002, 2003) studied the size distributions and formation of dicarboxylic acids in atmospheric particles and reported two distinct modes. The former was associated with gas condensation (about $0.2 \mu \mathrm{m}$ ), the latter called the droplet mode was associated with fog/cloud formation $(0.7 \mu \mathrm{m})$, consistent with our findings. They concluded that the aqueous reactions may be more important than gas phase photochemical reactions in oxalate formation. Our study suggests that HMOC particle types were not formed within the droplet mode, but in the interstitial air. Facchini et al. (1999) analysed samples of liquid droplets and interstitial aerosol collected during fog episodes, to determine how the organic compounds are partitioned between the two reservoirs. The interstitial aerosol was collected with a Hi-Vol collector, provided with a separator which excluded particles/droplets larger than $1.5 \mu \mathrm{m}$. It was found that fog acts as an efficient separator 
for carbon, with polar water-soluble species representing the greater part of total carbon within fog droplets, and waterinsoluble $\mathrm{C}$ species preferably found in the interstitial air. The different behaviour observed in that study may be because Facchini et al. (1999) were sampling a more oxidised, and hence hydrophilic regional aerosol remote from source, whereas in our work the secondary organic matter had probably formed recently from local emissions.

The fairly fast drop (Fig. 3a) in nitrate aerosol mass concentration detected by the AMS (from about 3.5 to $2.0 \mu \mathrm{g} / \mathrm{m}^{3}$ ) at about 11:00 a.m. coincides with the end of period 2 (fog event) and the beginning of period 3 (11:0012:30). The changes in the time series are also shown in the drop in particle number concentration of the APS (Fig. 3c). At around 10:45 a.m.-11:15 a.m. the fog began to dissipate, and the sharp decrease in AMS nitrate mass loading is due to the fewer and smaller droplets limiting the nitrate formation in the aqueous phase. The sharp drop in the nitrate concentration can as well be due to the decrease in the RH and the repartitioning of nitrate from the particle phase to the gas phase. However, the drop in nitrate production is also believed to be due to the partial evaporation of the fog water, slowing the nitrate production down in the liquid phase and leading to greater partitioning of nitrate to the gas phase.

The ATOFMS shows a continuing decrease in nitrate and HMOC particle types throughout period 3, but the variation is not as clear as the AMS mass loading.

Figure $3 b$ shows a unique ATOFMS particle type (CaSUL) detected during the end of the fog event (about 11:00 a.m.), and its mass spectra are shown in Fig. 4c. Whilst the positive mass spectrum is similar to the cluster Ca-EC (Fig. 4a), the negative spectrum is very different and presents a strong signature due to sulphate $(\mathrm{m} / \mathrm{z}-80$ and -97$)$. Cluster Ca-SUL was also detected in conjunction with the end of the HMS particle type spike. Although the number of particles associated with this particle type is small (about 50), we speculate that this particle type is related somehow with the disappearance of cluster HMS, indicating the end of the droplet mode containing HMS. We believe the Ca-SUL may be the residue of the droplet mode containing the HMS.

It is speculated that some of the Ca-EC particle type (likely to be already partially oxidised as strongly internally mixed with nitrate, Fig. 4a) acted as condensation nuclei during the fog event at about 08:30. Ca-SUL could be the result of the interaction between the aged Ca-EC particles and HMS or $\mathrm{SO}_{2}$. Recent results show that small changes in particle chemical composition caused by oxidation can increase the $\mathrm{CCN}$ activity of tropospheric aerosol particles (Prenni et al., 2007; Shilling et al., 2007). This study suggests that alterations of the aerosol chemical composition occurred during the measurement period, changing the hygroscopic nature of the $\mathrm{CCN}$ and decreasing their activation diameter.

Figure 3 shows that at about 12:30 p.m. a final change in the time series can be seen. This is the beginning of period 4, where all the fog was completely dissipated and all the atmospheric conditions changed. Figure 3 a shows a drastic reduction in nitrate concentration to less than $1 \mu \mathrm{g} / \mathrm{m}^{3}$, associated with a sharp increase of sulphate from about $1 \mu \mathrm{g} / \mathrm{m}^{3}$ to $4 \mu \mathrm{g} / \mathrm{m}^{3}$. Figure $3 \mathrm{c}$ shows the disappearance of the mode at about $0.9 \mu \mathrm{m}$ detected by the APS and Fig. 3e shows the concentrations of $\mathrm{O}_{3}$ suddenly increasing, associated with a slight decrease of the $\mathrm{NO}_{\mathrm{x}}$ concentrations. The increase in $\mathrm{O}_{3}$ is likely to be associated with convective downward mixing of ozone-rich air from aloft as the fog dissipated.

\section{Summary and conclusion}

An event of radiation fog was monitored by using two real time particle mass spectrometers as well as a number of other instruments in an urban background location in the city of London (UK). A unique chemical species (HMS) was detected in the droplet mode $(0.8-0.9 \mu \mathrm{m})$ during the fog event. Two other distinct types of particles were formed during the fog event. The former was rich in nitrate, distributed in the same droplet mode as the HMS particle type and hence thought to be formed in the aqueous phase. The latter was rich in high mass organic carbon chemical species, likely to be associated with HULIS, with a size distribution peaking in the smallest ATOFMS size range at about 200-300 nm. Contrary to previous studies, the formation of HULIS was observed on interstitial particles not in evaporated fog droplets, suggesting heterogeneous formation mechanisms depending on parameters other than the water content and not fully understood. This study shows how fog can drastically modify the atmospheric chemical and physical properties of the urban aerosol. It appears that secondary organic aerosol formation can occur rather rapidly under such conditions.

Acknowledgements. This research was supported by the UK Natural Environment Research Council as part of the programme of the National Centre for Atmospheric Science. Meteorological data, ozone and $\mathrm{NO}_{\mathrm{x}}$ data were provided by Eiko Nemitz (CEH Edinburgh). The authors are grateful also to the BOC Foundation for financial support of campaign expenses and to British Telecom and the Royal Parks for facilitating access to measurement sites.

Edited by: E. Nemitz

\section{References}

Abdalmogith, S. S. and Harrison, R. M.: An analysis of spatial and temporal properties of daily sulphate, nitrate and chloride concentrations at UK Urban and rural sites, J. Environ. Monit., 8, 691-699, 2006.

Alfarra, M. R., Paulsen, D., Gysel, M., Garforth, A. A., Dommen, J., Prevot, A. S. H., Worsnop, D. R., Baltensperger, U., and Coe, H.: A mass spectrometric study of secondary organic aerosols formed from the photooxidation of anthropogenic and biogenic precursors in a reaction chamber, Atmos. Chem. Phys., 6, 52795293, 2006,

http://www.atmos-chem-phys.net/6/5279/2006/. 
Allan, J. D., Jimenez, J. L., Coe, H., Bower, K. N., Williams, P. I., and Worsnop, D. R.: Quantitative sampling using an aerodyne aerosol mass spectrometer. Part 1: Techniques of data interpretation and error analysis, J. Geophys, Res. Atmos., 108(D3), 4090, doi:10.1029/2002JD002358, 2003.

Allan, J. D., Coe, H., Bower, K. N., Alfarra, M. R., Delia, A. E., Jimenez, J. L., Middlebrook, A. M., Drewnick, F., Onasch, T. B., Canagaratna, M. R., Jayne, J. T., and Worsnop, D. R.: Technical note: extraction of chemically resolved mass spectra from aerodyne aerosol mass spectrometer data, J. Aerosol Sci,, 35, 909922, 2004.

Altieri, K. E., Carlton, A. G., Lim, H. J., Turpin, B. J., and Seitzinger, S. P.: Evidence for oligomer formation in clouds: Reactions of isoprene oxidation products, Environ. Sci. Technol., 40, 4956-4960, 2006.

Andreae, M. O. and Gelencser, A.: Black carbon or brown carbon? The nature of light-absorbing carbonaceous aerosols, Atmos. Chem. Phys., 6, 3131-3148, 2006, http://www.atmos-chem-phys.net/6/3131/2006/.

Blando, J. D. and Turpin, B. J.: Secondary organic aerosol formation in cloud and fog droplets: a literature evaluation of plausibility, Atmos. Environ., 34, 1623-1632, 2000.

Canagaratna, M. R., Jayne, J. T., Jimenez, J. L., Allan, J. D., Alfarra, M. R., Zhang, Q., Onasch, T. B., Drewnick, F., Coe, H., Middlebrook, A., Delia, A., Williams, L. R., Trimborn, A. M., Northway, M. J., DeCarlo, P. F., Kolb, C. E., Davidovits, P., and Worsnop, D. R.: Chemical and microphysical characterization of ambient aerosols with the aerodyne aerosol mass spectrometer, Mass. Spectrom. Rev., 26(2), 185-222, 2007.

Cappiello, A., De Simon, E, Fiorucci, C., Mangani, F., Palma, P., Trufelli, H., Decesari, S., Facchini, M. C., and Fuzzi, S.: Molecular characterization of the water-soluble organic compounds in fogwater by ESIMS/MS, Environ. Sci. Technol., 37, 1229-1240, 2003.

Carlton, A. G., Turpin, B. J., Altieri, K. E., Seitzinger, S., Reff, A., Lim, H. J., and Ervens, B.: Atmospheric oxalic acid and SOA production from glyoxal: Results of aqueous photooxidation experiments, Atmos. Environ., 41, 7588-7602, 2007.

Carlton, A. G., Turpin, B. J., Lim, H. J., Altieri, K. E., and Seitzinger, S.: Link between isoprene and secondary organic aerosol (SOA): Pyruvic acid oxidation yields low volatility organic acids in clouds, Geophys. Res. Lett., 33, L06822, doi:10.1029/2005GL025374, 2006.

Dall'Osto, M. and Harrison, R. M.: Chemical characterisation of single airborne particles in Athens (Greece) by ATOFMS, Atmos. Environ., 40, 7614-7631, 2006.

DeCarlo, P. F., Kimmel, J. R., Trimborn, A., Northway, M. J., Jayne, J. T., Aiken, A. C., Gonin, M., Fuhrer, K., Horvath, T., Docherty, K. S., Worsnop, D. R., and Jimenez, J. L.: Field-deployable, high-resolution, time-of-flight aerosol mass spectrometer, Anal. Chem., 78, 8281-8289, 2006

Drewnick, F., Hings, S. S., DeCarlo, P., Jayne, J. T., Gonin, M., Fuhrer, K., Weimer, S., Jimenez, J. L., Demerjian, K. L., Borrmann, S., Worsnop, D. R.: A new Time-of-Flight Aerosol Mass Spectrometer (TOF-AMS) - instrument description and first field deployment, Aerosol Sci. Technol., 39, 637-658, 2005.

Ervens, B., Feingold, G., Frost, G. J., and Kreidenweis, S. M.: A modeling study of aqueous production of dicarboxylic acids: 1 . Chemical pathways and speciated organic mass production, J.
Geophys. Res.-Atmospheres, 109(D15), 2004.

Facchini, M. C., Fuzzi, S., Zappoli, S., Andracchio, A., Gelencser, A., Kiss, G., Krivacsy, Z., Meszaros, E., Hansson, H. C., Alsberg, T., and Zebuhr, Y.: Partitioning of the organic aerosol component between fog droplets and interstitial air, J. Geophys. Res.Atmospheres, 104(D21), 26821-26832, 1999.

Feng, J. S. and Moller, D.: Characterization of water-soluble macromolecular substances in cloud water, J. Atmos. Chem., 48, 217233, 2004.

Fuzzi, S., Facchini, M. C., Decesari, S., Matta, E., and Mircea, M.: Soluble organic compounds in fog and cloud droplets: what have we learned over the past few years?, Atmos. Res., 64, 89-98, 2002.

Gard E., Mayer, J. E., Morrical, B. D., Dienes, T., Fergenson, D. P., and Prather, K. A.: Real-time analysis of individual atmospheric aerosol particles: Design and performance of a porTable ATOFMS, Anal. Chem., 69, 4083-4091, 1997.

Gelencser, A. and Varga, Z.: Evaluation of the atmospheric significance of multiphase reactions in atmospheric secondary organic aerosol formation, Atmos. Chem. Phys., 5, 2823-2831, 2005, http://www.atmos-chem-phys.net/5/2823/2005/.

Graber, E. R. and Rudich, Y.: Atmospheric HULIS: How humiclike are they? A comprehensive and critical review, Atmos. Chem. Phys., 6, 729-753, 2006, http://www.atmos-chem-phys.net/6/729/2006/.

Gross, D. S., Galli, M. E., Kalberer, M., Prevot, A. S. H., Dommen, J., Alfarra, M. R., Duplissy, J., Gaeggeler, K., Gascho, A., Metzger, A., and Baltensperger, U.: Real-time measurement of oligomeric species in secondary organic aerosol with the aerosol time-of-flight mass spectrometer, Anal. Chem., 78, 2130-2137, 2006.

Gross, D. S., Galli, M. E., Silva, P. J., Wood, S. H., Liu D.-Y., and Prather, K. A.: Single particle characterization of automobile and diesel truck emissions in the Caldecott Tunnel, Aerosol Sci. Technol., 32, 152-163, 2000.

Henningan, C. J., Sullivan, A. P., Fountoukis, C. I., Nenes, A., Hecobian, A., Vargas, O., Case Hanks, A. T., Huey, L. G., Lefer, B. L., Russell, A. G. and Weber, R. J.: On the volatility and production mechanisms of newly formed nitrate and water soluble organic aerosol in Mexico City, Atmos. Chem. Phys. Discuss., 8, 4611-4829, 2008 .

Herckes, P., Chang, H., Lee, T., and Collett, J. L.: Air pollution processing by radiation fogs, Water Air and Soil Pollut., 181(14), 65-75, 2007a.

Herckes, P., Leenheer, J. A. and Collett, J. L.: Comprehensive characterization of atmospheric organic matter in Fresno, California fog water, Environ. Sci. Technol., 41, 393-399, 2007b.

Herckes, P., Lee, T., Trenary, L., Kang, G. G., Chang, H., and Collett, J. L.: Organic matter in Central California radiation fogs, Environ. Sci. Technol., 36, 4777-4782, 2002.

Herrmann, H., Ervens, B., Jacobi, H. W., Wolke, R.,. Nowacki, P, and Zellner, R.: CAPRAM2.3: A chemical aqueous phase radical mechanism for tropospheric chemistry, J. Atmos. Chem., 36(3), 231-284, 2000.

Herrmann, H.: Kinetics of aqueous phase reactions relevant for atmospheric chemistry, Chem. Rev., 103(12), 4691-4716, 2003.

Jimenez, J. L., Jayne, J. T., Shi, Q., Kolb, C. E., Worsnop, D. R., Yourshaw, I., Seinfeld, J. H., Flagan, R. C., Zhang, X., Smith, K. A., Morris, J. W., and Davidovits, P.: Ambient aerosol sampling 
using the Aerodyne aerosol mass spectrometer, J. Geophys. Res., 108(D7), 8425, 2003.

Kiss, G., Tombacz, E., Varga, B., Alsberg, T., and Persson, L.: Estimation of the average molecular weight of humic-like substances isolated from fine atmospheric aerosol, Atmos. Environ., 37, 3783-3794, 2003.

Kiss, G., Varga, B., Gelencser, A., Krivacsy, Z., Molnar, A., Alsberg, T., Persson, L., Hansson, H. C., and Facchini, M. C.: Characterisation of polar organic compounds in fog water, Atmos. Environ., 35, 2193-2200, 2001.

Kok, G. L., Gitlin, S. N., and Lazrus, A. L.: Kinetics Of The Formation And Decomposition Of Hydroxymethanesulfonate, J., Geophys. Res.-Atmos., 91(D2), 2801-2804, 1986.

Krivacsy, Z., Gelencser, A., Kiss, G., Meszaros, E., Molnar, A., Hoffer, A., Meszaros, T., Sarvari, Z. Temesi, D., Varga, B., Baltensperger, U., Nyeki, S., and Weingartner E.: Study on the chemical character of water soluble organic compounds in fine atmospheric aerosol at the Jungfraujoch, J. Atmos. Chem., 39, 235-259, 2001.

Lagrange, J., Wenger, G., and Lagrange, P.: Kinetic study of HMSA formation and decomposition: Tropospheric relevance, J. Chim. Phys. Phys.-Chim. Biol., 96(4), 610-633, 1999.

Laj, P., Fuzzi, S., Facchini, M. C., Orsi, G., Berner, A., Kruisz, C., Wobrock, W., Hallberg, A., Bower, K. N., Gallagher, M. W., Beswick, K. M., Colvile, R. N., Choularton, T. W., Nason, P., and Jones, B.: Experimental evidence for in-cloud production of aerosol sulphate, Atmos. Environ., 31, 2503-2514, 1997.

Lillis, D., Cruz, C. N., Collett, J., Richards, L. W., and Pandis, S. N.: Production and removal of aerosol in a polluted fog layer: model evaluation and fog effect on PM, Atmos. Environ., 33, 4797-4816, 1999.

Lim, H. J., Carlton, A. G., and Turpin, B. J.: Isoprene forms secondary organic aerosol through cloud processing: Model simulations, Environ. Sci. Technol., 39, 4441-4446, 2005.

Loeffler, K. W., Koehler, C. A., Paul, N. M., and De Haan, D. O.: Oligomer formation in evaporating aqueous glyoxal and methyl glyoxal solutions, Environ. Sci. Technol., 40, 6318-6323, 2006.

Moffet, R. C., de Foy, B., Molina, L. T., Molina, M. J., and Prather, K. A.: Measurement of ambient aerosols in northern Mexico City by single particle mass spectrometry, Atmos. Chem. Phys., 8(16), 4499-4516, 2008.

Murphy, D. M.: The design of single particle laser mass spectrometers, Mass Spectrom. Rev., 26, 150-165, 2007.

Ning, Z., Geller, M. D., Moore, K. F., Sheesley, R., Schauer, J. J., and Sioutas, C.: Daily variation in chemical characteristics of urban ultrafine aerosols and inference of their sources, Environ. Sci. Technol., 41, 6000-6006, 2007.

Noble, C. A. and Prather, K. A.: Real-time single particle mass spectrometry: A historical review of a quarter century of the chemical analysis of aerosols, Mass Spectrom. Rev., 19, 248274, 2000.

Prenni, A. J., Petters, M. D., Kreidenweis, S. M., DeMott, P. J., and Ziemann, P. J.: Cloud droplet activation of secondary organic aerosol, J. Geophys. Res.-Atmos., 112(D10), 2007.

Qin, X. Y. and Prather, K. A.: Impact of biomass emissions on particle chemistry during the California Regional Particulate Air Quality Study, Intl. J. Mass Spectrom., 258, 142-150, 2006.

Rebotier, T. P. and Prather, K. A.: Aerosol time-of-flight mass spectrometry data analysis: A benchmark of clustering algorithms,
Anal. Chim. Acta, 585, 38-54, 2007.

Reinard, M. S., Adou, K., Martini, J. M., and Johnston, M. V.: Source characterization and identification by real-time single particle mass spectrometry, Atmos. Environ., 41, 9397-9409, 2007.

Shilling, J. E., King, S. M., Mochida, M., and Martin, S. T.: Mass spectral evidence that small changes in composition caused by oxidative aging processes alter aerosol CCN properties, J. Phys. Chem. A, 111, 3358-3368, 2007.

Silva, P. J. and Prather, K. A.: Interpretation of mass spectra from organic compounds in aerosol time-of-flight mass spectrometry, Anal. Chem., 72, 3553-3562, 2000.

Song, X. H., Hopke, P. K., Fergenson, D. P., and Prather, K. A.: Classification of single particles analyzed by ATOFMS using an artificial neural network, ART-2A, Anal. Chem., 71, 860-865, 1999.

Spencer, M. T., Shields, L. G., Sodeman, D. A., Toner, S. M., and Prather, K. A.: Comparison of oil and fuel particle chemical signatures with particle emissions from heavy and light duty vehicles, Atmos. Environ., 40, 5224-5235, 2006.

Toner, S. M., Shields, L. G., Sodeman, D. A., and Prather, K. A.: Using mass spectral source signatures to apportion exhaust particles from gasoline and diesel powered vehicles in a freeway study using UF-ATOFMS, Atmos. Environ., 42, 568, 2008.

Warneck, P.: In-cloud chemistry opens pathway to the formation of oxalic acid in the marine atmosphere, Atmos. Environ., 37, 2423-2427, 2003.

Whiteaker, J. R. and Prather, K. A.: Hydroxymethanesulfonate as a tracer for fog processing of individual aerosol particles, Atmos. Environ., 37, 1033-1043, 2003.

Williams, P. I., McFiggans, G., and Gallagher, M. W.: Latitudinal aerosol size distribution variation in the Eastern Atlantic Ocean measured aboard the FS-Polarstern, Atmos. Chem. Phys., 7, 2563-2573, 2007, http://www.atmos-chem-phys.net/7/2563/2007/.

Yao, X.H., Fang, M., and Chan, C. K.: Size distributions and formation of dicarboxylic acids in atmospheric particles, Atmos. Environ., 36, 2099-2107, 2002.

Yao, X. H., Lau, A. P. S., Fang, M., Chan, C. K., and Hu, M.: Size distributions and formation of ionic species in atmospheric particulate pollutants in Beijing, China: 2 - dicarboxylic acids, Atmos. Environ., 37, 3001-3007, 2003.

Zhang, X., Smith, K. A., Worsnop, D. R., Jimenez, J. L., Jayne, J. T., and Kolb, C. E.: A numerical characterization of particle beam collimation by an aerodynamic lens-nozzle system. Part I: An individual lens or nozzle, Aerosol Sci. Technol., 36, 617-631 2002.

Zhang, X., Smith, K. A., Worsnop, D. R., Jimenez, J. L., Jayne, J. T., Kolb, C. E., Morris, J., and Davidovits, P.: Numerical characterization of particle beam collimation: Part II: Integrated aerodynamic lens-nozzle system, Aerosol Sci. Technol., 38, 619638, 2004.

Zhang, Q., Alfarra, M. R., Worsnop, D. R., Allan, J. D., Coe, H., Canagaratna, M. R., and Jimenez, J. L.: Deconvolution and quantification of hydrocarbon-like and oxygenated organic aerosols based on aerosol mass spectrometry, Environ. Sci. Technol., 39, 4938-4952, 2005. 